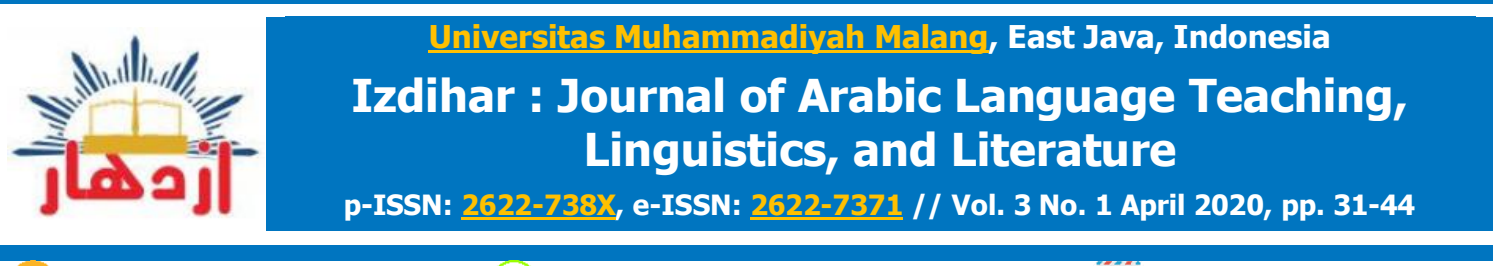

dol https://doi.org/10.22219/jiz.vol3i1.10967 http://ejournal.umm.ac.id/index.php/izdihar/index

\title{
Improving Arabic Speaking Skill through Mind Mapping Strategy
}

\author{
Miatin Rachmawatia, ${ }^{1}$, Fitria Nugrahaeni ${ }^{b, 2}$, Lailatul Mauludiyah ${ }^{c, 3}$ \\ a, bUniversitas Muhammadiyah Prof. Dr. HAMKA Jakarta, Indonesia \\ cUniversitas Muhammadiyah Malang, Indonesia \\ ${ }^{1}$ miatinrachmawati@uhamka.ac.id, ${ }^{2}$ fitria.nugrahaeni@uhamka.ac.id, ${ }^{3}$ elimauludiyah@umm.ac.id*
}

\section{ARTICLE INFO}

Article History:

Received: $14 / 01 / 2020$

Revised: 28/04/2020

Accepted: $29 / 04 / 2020$

Published: $30 / 04 / 2020$

\section{*Corresponding}

\section{Author:}

Name: Lailatul

Mauludiyah

Email:

elimauludiyah@umm.ac.id

\section{Keyword}

\section{ABSTRACT}

Mind mapping learning, that uses images and text with a purpose to describe the instructional ideas and concepts, gets lot attention by academicians. A renewal of Arabic learning method and strategy through mind mapping needs to be implemented in Arabic learning. The purpose of this study was to find out the implementation of Mind mapping to improve students' Arabic speaking skill. The research method used in this research was descriptive quantitative by emphasizing the improvement of students' speaking abilities and eliminating boredom in learning Arabic. The analysis process presented the results of scores carried out before and after the implementation of mind mapping in Arabic learning. The results of this study were mind mapping strategy was effective in learning Arabic, especially in learning speaking skills, because it gave students the courage to bring out new vocabulary they must master. The results were known from the difference between students' attitude and effectiveness of mind mapping before using this instructional strategy. Based on the percentage results, the success rate of learning rose by $30 \%$ and the level of boredom of students in learning decreased by $35 \%$. It means that this strategy can be implemented to improve Arabic speaking skill of students with joyful learning.

Copyright (C) 2020, Rachmawati et al This is an open access article under the CC-BY-SA license

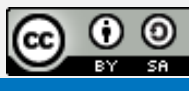

Boredom in Learning; Joyful Learning; Mind Mapping; Students' Attitude

\section{مستخلص البحث}

يحظى اهتمام الأكاديميين التعلم بالخرائط الذهنية التي تستخدم الصور والنصوص لغرض وصف الأفكار والمفاهيم التعليمية. يكون

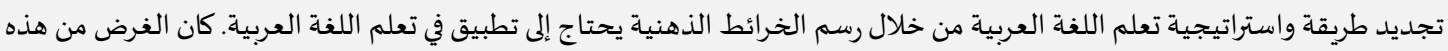

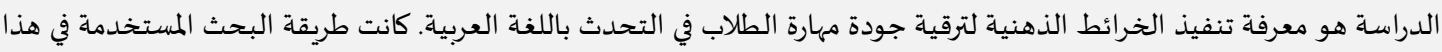

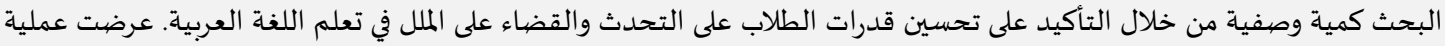

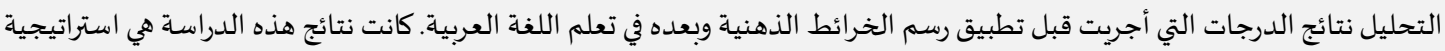

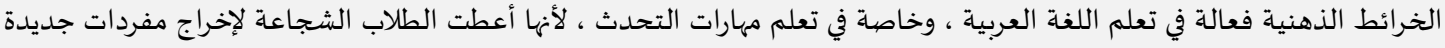

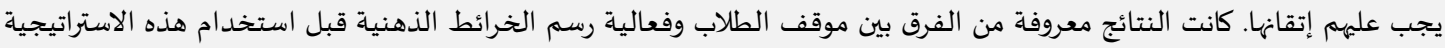

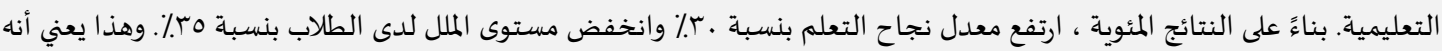

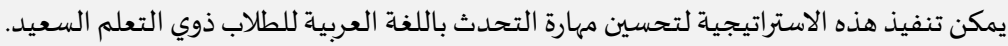

$$
\text { كلمات أسـاسية الملل في التعلم؛ التعلم السعيد؛ خريطة ذهنية؛ موقف الطلاب }
$$




\section{INTRODUCTION}

Learning Arabic involves four language skills, such as listening, speaking, reading, and writing skills. The four language skills are not easily mastered by students themselves without the help of the teacher's creativity. Musgamy (2018) said the learning atmosphere which is lethargic, stagnant, and less pleasant becomes a daily sight in learning Islamic studies both in religious schools or in public schools. The main concern of the four skill are the ability to speak, because the ability to speak is a determinant that someone can communicate using Arabic. Speaking is also a main skill if someone can use a foreign language.

Learning Arabic in MTs Muhammadiyah 1 Depok West Java is less challenging and less varied in the learning models and methods, and this is one of the causes of the lack of interest of students in learning Arabic. There are several reasons that make students not interested in learning Arabic, one of them is because some teachers are monotonous in teaching and lack of facilities in learning Arabic. Around 45\% of students were happy with Arabic learning process, they were fluent in understanding Arabic. About $55 \%$ of students did not like to the subject, even found some obstacles in learning Arabic. Around $35 \%$ of them were reluctant and lazy in speaking Arabic and about $25 \%$ of them felt bored with the learning method that teachers used. If student's interest in Arabic is low, the learning objectives will not be revealed. Therefore, learning Arabic needs an innovation as a solution to these problems.

Apart from external factors, internal factors that inhibit speaking skill learning are (1) phonemic distortion as an articulation problem, (2) stuttering problems that are individual, (3) disruption of articulation of words due to pronunciation that is too fast, (4) listening to the difficulties caused by sounds that are too loud or too soft, (5) learners speak formally to the instructor or other students in a low or a loud voice. In addition, the language learning curriculum is also an important thing to consider to support students' speaking skills (Aziz, 2019).

The main solution in learning Arabic is the creativity of the teacher in making media. The study results have shown that media use is very useful in teaching and learning activities, especially in improving student learning achievement. In addition to learning media, learning strategies are also important in learning activities. The results show that there is a relationship between several language learning strategies and speaking ability, but this depends on the diversity of individuals (Pietrzykowska, 2014). Some creativity has been done by teachers to improve students' ability in speaking skills. Among them is using a conversation method that includes all elements of speaking skills even though the ability of students is very varied. The elements 
are new vocabulary, eloquence, makharijul huruf, intonation, and tenses (morphology) (H. Nur, 2017). In other studies, it was found that both orthographic and phonological knowledge contributed to real spelling and pseudo word. The implications of these findings are discussed in relation to language teaching policy and pedagogy (Russak \& Fragman, 2014). This statement is reinforced in other studies which found that phonological awareness and orthographic processing skills were quite important for successful word recognition in English (Ji \& Baek, 2019), this research is for L2 in English but also has the same implications in L2 in Arabic.

In addition, the learning media that have been used are cartoon film, in this study students are motivated to learn Arabic so that students are more easily stimulated and are able to improve speaking skills (C. Nur, 2019). One of the other medias is snake ladder media. This media is used to increase students' vocabulary and then help students to improve their speaking skill (Nurlaila, 2018). In addition, to improve students' language skills digital media can also be used (Fauzi, 2019).

Besides the two media, the most widely used are Liquid Cristal Display (LCD), quizzes, brainstorming and others. From various media that have been used, researchers need to try media that has never been used before, it is mind mapping. Mind mapping has been widely used for writing skills. A study conducted Azizah (2013) explained that the use of mind mapping strategies can help the memory of the material and affect the optimization of learning outcomes. In addition, this mind mapping strategy can also help in growing ideas. Then it helps students to develop their ideas. Researchers applied this mind mapping to improve speaking skills.

A mind mapping is a way to take notes that are not boring, because the mental map consists of words, colors, lines, and pictures. Mind mappings are prepared using images and text to describe ideas and concepts learned (Nauli, 2013). It is impossible to solve some of the problems faced by Arabic language teachers today with the exception of good learning planning and the teacher's experience in managing and implementing learning (Fatmawati, 2014).

Mapping concept can visually show the various paths that can be taken in connecting conceptual understanding in the problem. Mapping concept created by students can help teachers to recognize the misconceptions students have and to strengthen the teacher's own conceptual understanding and scientific discipline. In addition, the mapping concept is a good way for students to understand and remember a number of new information (Fujiawati, 2016). According to Edward (2009) mind mapping is the most effective and efficient way to enter, store, and extract data from or to the brain. 
Mind mapping strategy was popularized by Tony Buzan. Mind mapping is a system of storage, data retrieval, and extraordinary access to giant libraries, which actually exist in the amazing brain, because mind mapping helps to compile and store as much information as desired, and classify it in a natural way (Buzan, 2009). An analysis of the use of mind mapping states that the use of mind mapping in learning foreign languages can increase motivation and make the learning atmosphere more enjoyable. The use of mind mapping strategies can help the memory of the material and affect the optimization of learning outcomes. In addition this mind mapping strategy can also help in growing ideas or ideas so that it helps students develop their ideas (S. Azizah, 2013). The mind mapping-based learning concept uses images and text to illustrate the ideas and concepts learned (Zarkasyi, 2014).

The aim of this research was to improve the Arabic speaking skills, especially in memorizing Arabic vocabulary. Arabic language is the religious language of a billion Muslims all over the world, which is spoken in daily worship, and Arabic is the language that carries the most of attributes. Arabic language has unusual privileges compared to other languages, because of the high-quality literary value for those who study it and Arabic is the language of the Qur'an which transmits the words of God. Arabic language amazed the language society and no one can compare it. In learning Arabic, this article has a contribution in providing solutions for language teachers to be able to teach speaking skill with interesting media and become a new color in learning Arabic.

\section{METHOD}

The research method was descriptive quantitative research. According to the research was to describe the results of learning by using the mind mapping method. The implementation of the media was carried out in class 7A with a total of 32 students from a total population of 52 students in class 7 . The research was conducted in class $7 \mathrm{~A}$ because of the ability of students to be very heterogenic. So, this media is expected to be able to reach level the ability of students in the class.

The assessment was done by distributing questionnaires before and after the implementation of this media. The questionnaire used was a closed questionnaire that would measure three things: speaking skills, motivation to learn, and things that made the spirit of learning. While data analysis used the percentage formula. From calculations using the percentage formulas, then the data findings were described and integrated with existing theories and then concluded to be a research result. 


\section{First step}

The first thing to do in implementing Mind Mapping is to provide basic material. The teacher gave basic material on vocabulary about "colors, edges,

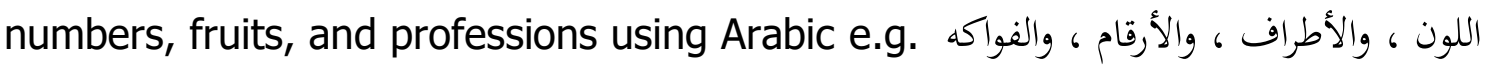

g والمهن. Students understand and memorize the material correctly. After that, they will get used to using the new vocabulary they have learned before.

\section{Second step}

Students determine the sub topics and make a title of the sub topics. The title was used as a subject that was practiced in speaking skills. By knowing the topics and sub topics they get, students can focus on practicing from what they have already gotten.

\section{Third step}

After choosing the topic of discussion, students explain and discuss using good Arabic in accordance with grammar. The results of this study were used as a reference for implementing Arabic learning using mind mapping method to improve speaking skills. The interpretation of this step was the essence of speaking skills. Students become energetic and creative in learning Arabic and applying Arabic words in simple sentences to story forms. This step trains students' speaking skills by presenting topics in front of the class one by one and discussing the sub-topics they are working on, while the other students listen seriously to the explanation from the speaker.

\section{RESULTS \& DISCUSSION}

Speaking skill is the ability to express vocabulary, words, and sounds to transmit ideas in the form of opinions, desires, thoughts, or feelings to a speaking partner. Syamaun (2016) said In the widest meaning, speaking is a system that can be heard and seen that uses a number of muscles of the human body to transmit ideas in order to meet the needs in human life. Embi and Teh (2009) said language learning strategies are specific steps or procedures that students have taken to facilitate the acquisition, storage, initial access, and use of information to make learning easier, faster, enjoyable, effective, and to take students to a new atmosphere as it involves a mental and communication procedure for learning and using the language in the context of promoting language acquisition and mastery of the goal.

The results obtained by researchers that the implementation of mind mapping learning method is very effective in learning Arabic. This is evident from the questionnaire which showed that students interested in Arabic (fluent 
in understanding Arabic) increased to $77 \%$. Around $13 \%$ of students are still lazy in participating in learning Arabic, while students who are still bored in learning Arabic decreased by $10 \%$.

Table 1. The Results of the Student Satisfaction Survey with the Mind Mapping method

\begin{tabular}{|cccc|}
\hline No. & \multicolumn{1}{c}{ Students' situation } & $\begin{array}{c}\text { Before } \\
(\mathbf{\%})\end{array}$ & $\begin{array}{c}\text { After } \\
(\mathbf{\%})\end{array}$ \\
\hline 1. & Fluency in understanding and speaking & 40 & 77 \\
\hline 2. & Lazy speaks Arabic & 35 & 13 \\
\hline 3. & Tired in learning Arabic & 25 & 10 \\
\hline & Total & 100 & 100 \\
\hline
\end{tabular}

From Table 1, it can be concluded that the mind mapping method is effective in learning Arabic, especially in improving speaking skills. This method encourages students' courage to bring out new vocabulary that they must master. There are significant differences in the mastery of students' speaking skills before and after using the mind mapping method shows that the use of the method is effective. In implementation, the media used in learning are shown in Figure 1.

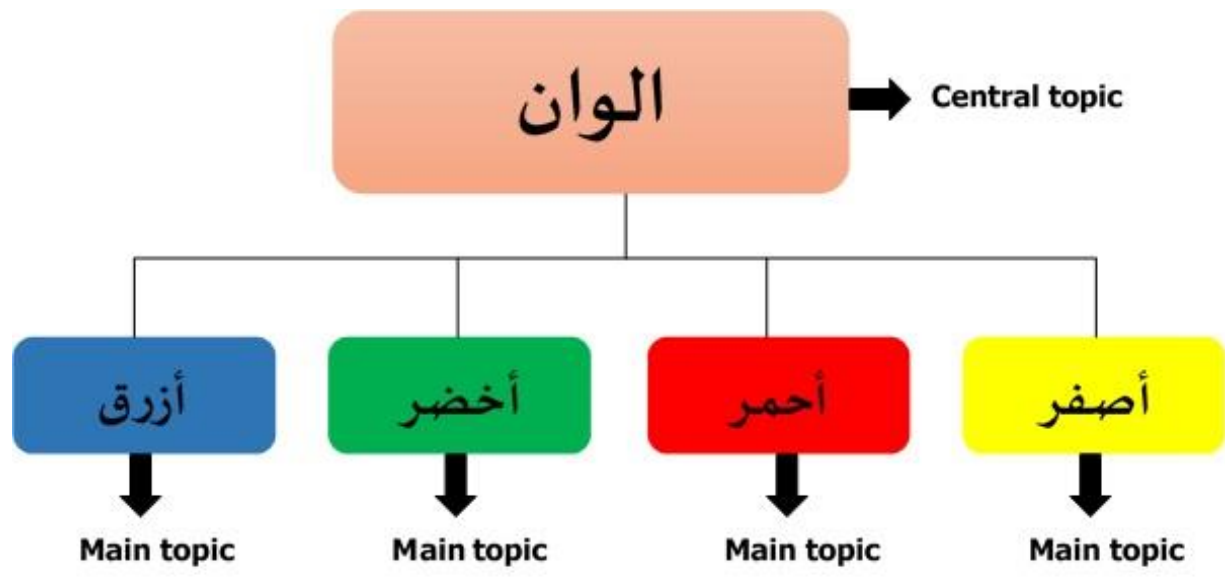

Figure 1 : Basic Materials

Figure 1 explains the material map used in mind mapping. This mapping will make easier for students to arrange vocabulary into one sentence. In this mind mapping there is a central topic to explain the main topic to be studied and main topic to explain the main topic fraction. 


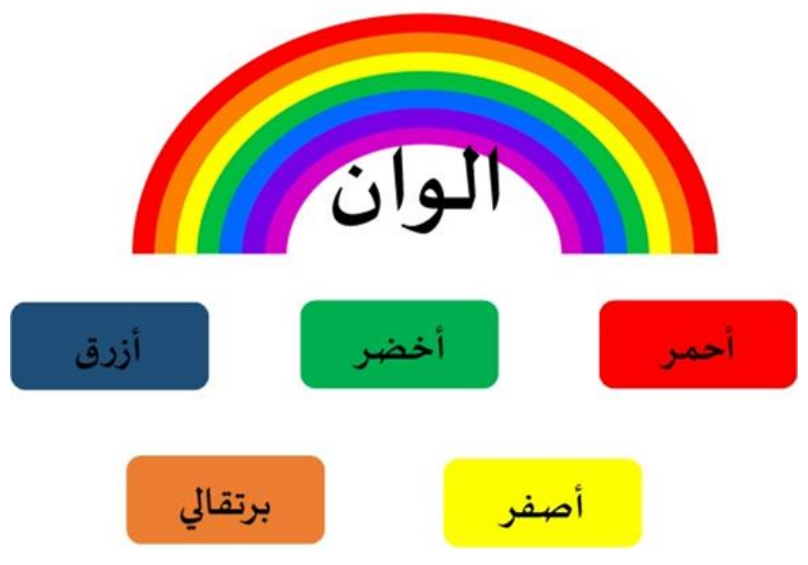

Figure 2. Materials Selected by Students

Figure 2 explains the sub material that students chose in the learning process. Sub material was developed into a title for speaking skill.

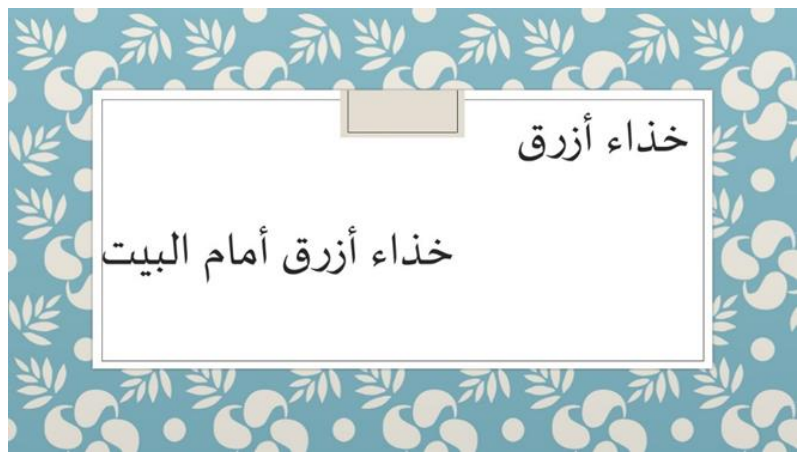

Figure 3. Mind Mapping in Improving Speaking Skills

Figure 3 is an example of developing the title of a sub-theme. The main title would be developed into a sentence

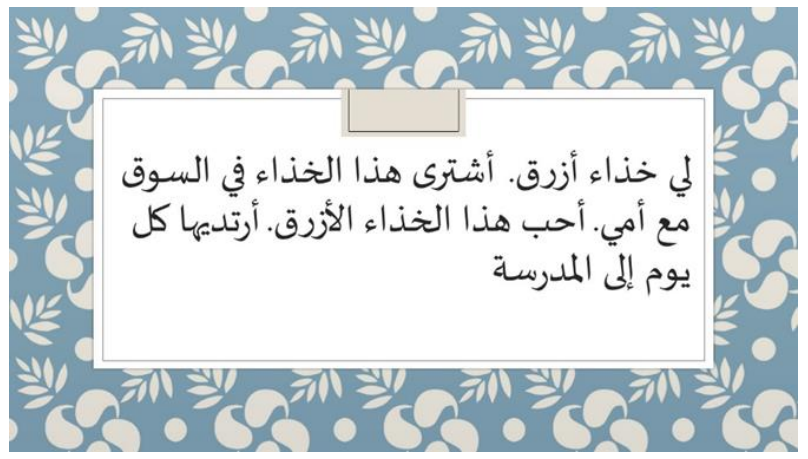

Figure 4. The Sentence that was Brought up when Speaking Arabic

Figure 4 is an intact form of the process of forming sentences through mind mapping. From this form, students were given time to say the sentences that have been made without looking at the text.

Please cite this article as Rachmawati, M., Nugrahaeni, F., Mauludiyah, L. (2020). Improving Arabic Speaking Skill through Mind Mapping Strategy. Izdihar : Journal of Arabic Language Teaching, Linguistics, and Literature, 3(1), 31-44. DOI: https://doi.org/10.22219/jiz.v3i1.10967 
Learning Arabic as a foreign language was considered difficult for a lot of students. For this reason, a stimulus is needed to make it easier for students to understand. At the age of the child, it will be easier to learn and understand something with important pieces of things. Students will have difficulty understanding something with a long descriptive. In addition, in the learning process, students also need to increase concentration to capture the material presented properly. Therefore, using the mind mapping method students will be helped because they will look for potential pieces of ideas to become one idea (S. N. Azizah, 2015). In the stimulus process, auditory processing, languagespecific prosody awareness, and phonological awareness play different roles in L1/L2 readings, reflecting different prosodic and segmental structures (Chung, Jarmulowicz, \& Bidelman, 2017).

In the attention process, there are several aspects that must be considered, namely: a) concentration or control of attention. Attention can increasingly be maintained (persistence) with age. Children's interests also influence their attention, for example simple thing attracts more attention than a complex one; b) adaptation (adaptability). Screening for relevant information is needed, even though irrelevant information often provides a situation of "incidental learning"; c) planning (plan-fullness). The strategy of directing attention with a systematic and organized planning can improve the efficiency of filtering irrelevant information; d) adaptation of attention with increasing age. With increasing age, children are better able to use more complex information processing systems and are better able to complete their focus of attention with existing information. Nuryana and Purwanto (2010) said that children become more flexible and better able to adapt their attention strategies.

For psychological children at Islamic junior school education level, students have not been able to do systematic thinking and have not been able to do full concentration during learning. For the mind mapping work process, children are stimulated to begin to receive words then they are taught to think systematically through the activity of making sentences then arranging them into a paragraph. So, this process helps the learning process of speaking to students.

Learning using mind mapping can stimulate memory and thinking skills as well as the ability to manage what should be conveyed from within the student's brain. In addition, the use of mind mapping also makes students more interested in learning. Mind mapping can also be used as a measuring tool to assess students' understanding during the learning process. Mind mappings are also able to organize the main ideas that students previously find it difficult. (Laungeng, 2016). 
A study of mind mapping used in language learning shows that mind mapping technique can be successfully implemented in the language learning classroom, providing creative and available tool for students, educators and researchers (Buran \& Filyukov, 2015). The use of mind mapping in the learning process makes learning based on student-centered so that teachers only become facilitators and assist students in the implementation of learning.

While other studies said that some students have learning problems in class because the notes given by teachers do not match their learning style. With mind mapping, students can personalize their notes using words, arrows, and abbreviations to bring together new ideas. They can use images, borders and colors in their mind mapping and then use them as study reviews for all courses (Fun \& Maskat, 2010). The practice in this research, students independently make a statement that is expressed in the form of speaking skills through stimulus from the teacher.

Buzan (2009) in his book said that powerful graphic techniques provide a universal key to unlock the full potential of the human brain so that it can use all the abilities that exist in both hemispheres such as words, images, numbers, logic, rhythm, and color in an unique way. Mind mapping is one of the easiest ways to put information into the brain and take information out of the brain. Lubis, Syahrul, and Juita, (2014) said mind mappings can help students learn to compile and store as much information as they want and how to group them is done naturally, by giving easy and direct access to something they want. With a variety of advantages, mind mappings are predicted to make it easier for students to write essays systematically.

After the maturation of the concept by students, the teacher provide a stimulus in terms of practice. The balance of the two things is able to produce a learning outcome that is certainly in accordance with the target. So that the process of delivering students in expressing sentences in speaking skills has been organized and is able to produce good sentences. It would also be better if this concept map was combined with a group game (Fauzi, Buhun, \& Purwadi, 2019).

Speaking skills (Maharah al-Kalam) is someone's ability to pronounce articulation of Arabic sounds (Ashwat 'Arabiyyah) or words with linguistic rules (Qawa'id Nahwiyyah wa Sharfiyyah) to convey ideas and feelings (Roziqi, 2020). Therefore teaching Arabic to non-Arabs in the early stages has the following objectives: to enable students to pronounce the sounds of Arabic correctly (especially those that have no immediate analogue in other languages) and with proper intonation, can pronounce the sounds of letters close to each other together, can distinguish between long and short harakat pronunciation, able to express ideas with complete sentences in various 
conditions, able to speak in simple sentences with the appropriate tone and intonation, can speak in formal situations with a series of simple and short sentences, and able to speak fluently around general topics (Rahmaini, 2015).

The three speaking strategy groups that teachers must have are expression practice strategy, native-like and involvement strategy and assistance strategy. The expression practice strategy is reviewing words periodically to remember and use them, write down useful words and phrases, and try to use them, practice to say new expressions to yourself (Sun, Zhang, \& Gray, 2016). In the concept of mind mapping for speaking skills, using steps from the expression practice strategy can get maximum results in the transfer of new vocabulary to the practice of uttering sentences.

Students can make simple communication in Arabic and can understand simple readings in a discourse, vocabulary (mufradat) must be remembered outside of the head, because mufradat will be useful for students in communication (Syamaun, 2016). For this reason, in the process of implementing learning by using mind mapping, the first step used is word-forword recognition then guided to be able to produce long sentences. So, from this process, it was shown that learning with concept maps is very helpful in organizing students' abilities in producing sentence structures when applied to speaking skills (maharah kalam).

In the equalization ability to speak, teachers can use students's classmates who are already proficient to help improve vocabulary and sentence formation in other students. Clinical educators developed unique coping strategies that they used on a case-by-case basis to assess students and ensure adequate client management when they experienced such language barriers while supervising. Coping strategies included engaging other students as interpreters, having students role-play parts of a session in English in advance and requesting real-time translations from the student during the session (Keeton, Kathard, \& Singh, 2017). This form of clinical editor implementation in mind mapping learning was applied in every group so that all students are able to reach the learning targets.

\section{CONCLUSIONS}

The process of marking with a mind map is a way to take notes that are not boring, because the mind map is made up of words, colors, lines and images. Mind mappings aim to make a visual and graphically engraved topic that can ultimately help record, strengthen, and restore learned information. Therefore, mind mapping is a way to take notes that develop visual learning styles. Learning with mind mappings helps students to improve speaking skills. 
According to the results of the study, there was an increase of $32 \%$ and also because it was not a boring method, learning activities with the concept map also increased student motivation, as evidenced by a decrease in the level of boredom of students when learning Arabic. The next researcher is expected to be able to develop this media based on digital. So it can be used by students for blended learning.

\section{ACKNOWLEDGMENT}

Our gratitude also goes to Rector of Universitas Muhammadiyah Prof. Dr. HAMKA Jakarta for providing the Baitul Arqom research budget for being able to carry out this research at 2019.

\section{BIBLIOGRAPHY}

Aziz, M. (2019). Understanding English Speaking Difficulties: Implications for the English Language Curriculum for the Arab Students in a Pakistani University. In English Language Teaching Research in the Middle East and North Africa (pp. 351-382). Springer.

Azizah, S. (2013). Efektivitas Penggunaan Strategi Mind Mapping Mata Kuliah Writing. NUANSA: Jurnal Penelitian I/mu Sosial Dan Keagamaan Islam, 10(2), 51-63. DOI: https://dx.doi.org/10.19105/nuansa.v10i2.175

Azizah, S. N. (2015). Peningkatan Konsentrasi dan Hasil Belajar IPA Melalui Mind Mapping Siswa Kelas V SDN Jomblangan. BASIC EDUCATION, 4(5), 13. DOI: https://doi.org/10.23917/indigenous.v12i1.1558

Buran, A., \& Filyukov, A. (2015). Mind mapping technique in language learning. Procedia-Social and Behavioral Sciences, 206, 215-218. DOI:

https://doi.org/10.1016/j.sbspro.2015.10.010

Buzan, T. (2009). Buku pintar mind mapping. Jakarta: PT. Gramedia Pustaka Utama.

Chung, W.-L., Jarmulowicz, L., \& Bidelman, G. M. (2017). Auditory processing, linguistic prosody awareness, and word reading in Mandarin-speaking children learning English. Reading and Writing, 30(7), 1407-1429. DOI: https://doi.org/10.1007/s11145-017-9730-8

Edward, C. (2009). Mind Mapping untuk anak sehat dan cerdas. Yogyakarta: Sakti.

Fatmawati, B. (2014). Identifikasi Berpikir Kreatif Mahasiswa Melalui Metode Mind Mapping. Bioedukasi: Jurnal Pendidikan Biologi, 72), 1-4. DOI: https://doi.org/10.20961/bioedukasi-uns.v7i2.2924 
Fauzi, M. F. (2019). Tathwiir Al-Ghoz Ar-aqmii limaddati Tahbiiq Ash-sharf 1 'ala Haatif Mahmul Katadriibaat Al-idhofiyyah Khorij Al-Fash Ad-Diroosi. Buletin Al-Turas, 25(1), 129-139. DOI: https://doi.org/10.15408/bat.v25i1.11506

Fauzi, M. F., Buhun, M. F., \& Purwadi, A. (2019). The Influence of Teams Games Tournament (TGT) toward Students' Interest in Arabic Language Learning. Izdihar: Journal of Arabic Language Teaching, Linguistics, and Literature, 2(2), 135-148. DOI: https://doi.org/10.22219/jiz.v2i2.9986

Fujiawati, F. S. (2016). Pemahaman Konsep Kurikulum Dan Pembelajaran Dengan Peta Konsep Bagi Mahasiswa Pendidikan Seni. JPKS (Jurnal Pendidikan Dan Kajian Seni), 1(1),16-28. DOI: https://dx.doi.org/10.30870/jpks.v1i1.849

Fun, C. S., \& Maskat, N. (2010). Teacher-centered mind mapping vs studentcentered mind mapping in the teaching of accounting at pre-U Level-An action research. Procedia-Social and Behavioral Sciences, 7, 240-246. DOI: https://doi.org/10.1016/j.sbspro.2010.10.034

Ji, M., \& Baek, S. (2019). Native Korean-Speaking Children Learning to Read in English: A Structural Analysis of L2-English Literacy Acquisition. Journal of Psycholinguistic Research, 48(2), 391-415. DOI: https://doi.org/10.1007/s10936-018-9610-7

Keeton, N., Kathard, H., \& Singh, S. (2017). Clinical educators' experiences of facilitating learning when speaking a different language from both the student and client. BMC Research Notes, 10(1), 546-553. DOI: https://doi.org/10.1186/s13104-017-2874-4

Laungeng, S. H. (2016). Strategi Peta Konsep Dan Strategi Tradisional Terhadap Pencapaian Komsas Dalam Bahasa Melayu Pelajar Tingkatan 4 (Concept Map Strategy and Traditional Strategy Form 4 Students Achievement in Literature Component in Malay Language). Jurnal Pendidikan Bahasa Melayu, 6(1), 30-37.

http://spaj.ukm.my/jpbm/index.php/jpbm/article/view/106

Lubis, M. S., Syahrul, R., \& Juita, N. (2014). Pengembangan Modul Pembelajaran Bahasa Indonesia Berbantuan Peta Pikiran Pada Materi Menulis Makalah Siswa Kelas XI SMA/MA. Bahasa, Sastra, Dan Pembelajaran, 2(1), 16-28. http://ejournal.unp.ac.id/index.php/bsp/article/view/5026

Musgamy, A. (2018). Quantum Learning Sebagai Proses Pembelajaran Bahasa Arab Aktif, Inovatif, Kreatif, Efektif Dan Menyenangkan. Al Daulah: Jurnal Hukum Pidana Dan Ketatanegaraan, 6(1), 145-155. DOI: https://doi.org/10.24252/ad.v6i1.4871

Nauli, H. (2013). Pengaruh Metode Mind Mapping terhadap Hasil Belajar Siswa Materi Lingkaran di SMP. Jurnal Pendidikan Dan Pembelajaran Khatulistiwa, 
2(9), 1-12. http://jurnal.untan.ac.id/index.php/jpdpb/article/view/3215

Nur, C. (2019). Efektivitas Penggunaan Media Film Kartun terhadap Peningkatan Maharah Al-Kalam Peserta Didik. Diwan: Jurnal Bahasa Dan

Sastra Arab, 5(1), 92-105. DOI:https://doi.org/10.24252/diwan.v5i1.6801

Nur, H. (2017). Penerapan Metode Muhadatsah dalam Meningkatkan Hasil

Belajar Maharah Kalam Peserta Didik. Lentera Pendidikan: Jurnal IImu

Tarbiyah Dan Keguruan, 20(2), 177-187.

DOI:https://doi.org/10.24252/lp.2017v20n2i4

Nurlaila, A. R. (2018). Penggunaan Media Ular Tangga Untuk Meningkatkan Kemahiran Berbicara Bahasa Arab Siswa Pondok Pesantren Darul Hikmah Soncolela Kota Bima. AL-AF'IDAH: Jurnal Pendidikan Bahasa Arab Dan Pengajarannya, 2(1), 52-68.

http://ejournal.iaimbima.ac.id/index.php/afidah/article/view/164

Nuryana, A., \& Purwanto, S. (2010). Efektivitas brain gym dalam meningkatkan konsentrasi belajar pada anak. Indigenous: Jurnal Ilmiah Psikologi, 12(1), 88-98. DOI: https://doi.org/10.23917/indigenous.v12i1.1558

Pietrzykowska, A. (2014). The relationship between learning strategies and speaking performance. In Classroom-oriented Research (pp. 55-68). Springer.

Rahmaini, R. (2015). Strategi Pembelajaran Maharah Kalam Bagi Non Arab. Ihya Al-Arabiyah: Jurnal Pendidikan Bahasa Dan Sastra Arab, 1(2), 227233. http://jurnal.uinsu.ac.id/index.php/ihya/article/view/1529/0

Roziqi, M. A. (2020). Development of Pictorial Textbook for Arabic Speaking Skill in Islamic Studies Program. Izdihar: Journal of Arabic Language Teaching, Linguistics, and Literature, 2(3), 217-230. DOI: https://doi.org/10.22219/jiz.v2i3.10161

Russak, S., \& Fragman, A. (2014). Spelling development in Arabic as a foreign language among native Hebrew speaking pupils. Reading and Writing, 272), 359-381. DOI: https://doi.org/10.1007/s11145-013-9448-1

Sun, P. P., Zhang, L. J., \& Gray, S. M. (2016). Development and Validation of the Speaking Strategy Inventory for Learners of Chinese (SSILC) as a Second/Foreign Language. The Asia-Pacific Education Researcher, 25(4), 593-604. DOI: https://doi.org/10.1007/s40299-016-0287-0

Syamaun, N. (2016). Pembelajaran Maharah al-Kalam untuk Meningkatan Keterampilan Berbicara Mahasiswa Program Studi Pendidikan Bahasa Arab Fakultas Tarbiyah dan Keguruan UIN Ar-Raniry Banda Aceh. Jurnal.ArRaniry.Ac.Id, 343-359. DOI: https://dx.doi.org/10.22373/l.v4i2.852

Teh, K. S. M., \& Embi, M. A. (2009). Korelasi Strategi dengan Motivasi dalam Pembelajaran Bahasa Arab. Jurnal Pendidik Dan Pendidikan, 24, 109-123. https://core.ac.uk/reader/83543418

Please cite this article as Rachmawati, M., Nugrahaeni, F., Mauludiyah, L. (2020). Improving Arabic Speaking Skill through Mind Mapping Strategy. Izdihar : Journal of Arabic Language Teaching, Linguistics, and Literature, 3(1), 31-44. DOI: https://doi.org/10.22219/jiz.v3i1.10967 
Zarkasyi, A. H. (2014). Waqi' At-Ta'liim Al-Lughoh Al-Arabiyyah fi al-Ma'aahid wa Almadaaris bi Indunisiyyah. LISANUDHAD, 1(2). 11-24. DOI: http://dx.doi.org/10.21111/lisanudhad.v1i2.451 